\title{
Pharmacological and Biochemical Characterization of TLQP-21 Activation of a Binding Site on CHO Cells
}

\author{
Laura Molteni 1,2, Laura Rizzi', Elena Bresciani', Roberta Possenti3, \\ Pamela Petrocchi Passeri ${ }^{3}$, Corrado Ghè ${ }^{4}$, Giampiero Muccioli ${ }^{4}$, Jean-Alain Fehrentz ${ }^{5}$, \\ Pascal Verdiés, Jean Martinez ${ }^{5}$, Robert J. Omeljaniuk ${ }^{6}$, Giuseppe Biagini ${ }^{7}$, Anna Binda', \\ Ilaria Rivolta ${ }^{1}$, Vittorio Locatelli ${ }^{1}$ and Antonio Torsello ${ }^{1 *}$

\begin{abstract}
${ }^{1}$ Department of Medicine and Surgery, University of Milano-Bicocca, Monza, Italy, ${ }^{2}$ PhD Program in Neuroscience, Department of Medicine and Surgery, University of Milano-Bicocca, Monza, Italy, ${ }^{3}$ Department of Medicine of Systems, University of Rome "Tor Vergata", Rome, Italy, ${ }^{4}$ Department of Drug Science and Technology, University of Turin, Turin, Italy, ${ }^{5}$ Centre National de la Recherche Scientifique, Max Mousseron Institute of Biomolecules UMR5247, University of Montpellier, École Nationale Supérieure de Chimie de Montpellier, Montpellier, France, ${ }^{6}$ Department of Biology, Lakehead University, Thunder Bay, ON, Canada, ${ }^{7}$ Laboratory of Experimental Epileptology, Department of Biomedical, Metabolic and Neural Sciences, University of Modena and Reggio Emilia, Modena, Italy
\end{abstract}

\section{OPEN ACCESS}

Edited by:

Eero Vasar,

University of Tartu, Estonia

Reviewed by:

Victor M. Arce,

Universidade de Santiago de Compostela, Spain

Jaanus Harro,

University of Tartu, Estonia

Andrew Harkin,

Trinity College, Dublin, Ireland

*Correspondence:

Antonio Torsello

antonio.torsello@unimib.it

Specialty section:

This article was submitted to

Neuropharmacology,

a section of the journal

Frontiers in Pharmacology

Received: 21 December 2016 Accepted: 14 March 2017

Published: 30 March 2017

Citation:

Molteni L, Rizzi L, Bresciani E, Possenti R, Petrocchi Passeri P, Ghè C, Muccioli G, Fehrentz J-A, Verdié P, Martinez J, Omeljaniuk RJ,

Biagini G, Binda A, Rivolta I,

Locatelli V and Torsello A (2017)

Pharmacological and Biochemical

Characterization of TLQP-21

Activation of a Binding Site on $\mathrm{CHO}$

Cells. Front. Pharmacol. 8:167.

doi: 10.3389/fphar.2017.00167
VGF is a propeptide of 617 amino acids expressed throughout the central and the peripheral nervous system. VGF and peptides derived from its processing have been found in dense core vesicles and are released from neuronal and neuroendocrine cells via the regulated secretory pathway. Among VGF-derived neuropeptides, TLQP21 (VGF $^{556-576}$ ) has raised a huge interest and is one of most studied. TLQP-21 is a multifunctional neuropeptide involved in the control of several physiological functions, potentially including energy homeostasis, pain modulation, stress responsiveness and reproduction. Although little information is available about its receptor and the intracellular mechanisms mediating its biological effects, recent reports suggest that TLQP-21 may bind to the complement receptors C3aR1 and/or gC1qR. The first aim of this study was to ascertain the existence and nature of TLQP-21 binding sites in $\mathrm{CHO}$ cells. Secondly, we endeavored to characterize the ligand binding to these sites by using a small panel of VGF-derived peptides. And finally, we investigated the influence of TLQP-21 on selected intracellular signaling pathways. We report that $\mathrm{CHO}$ cells express a single class of saturable and specific binding sites for TLQP-21 with an affinity and capacity of $K_{\mathrm{d}}=0.55 \pm 0.05 \times 10^{-9} \mathrm{M}$ and $B_{\max }=81.7 \pm 3.9 \mathrm{fmol} / \mathrm{mg}$ protein, respectively. Among the many bioactive products derived from the $\mathrm{C}$-terminal region of VGF that we tested, TLQP-21 was the most potent in stimulating intracellular calcium mobilization in $\mathrm{CHO}$ cells; this effect is primarily due to its C-terminal fragment $(\mathrm{HFHH}-$ 10). TLQP-21 induced rapid and transient dephosphorylation of phospholipase $C_{\gamma} 1$ and phospholipase A2. Generation of $\mathrm{IP}_{3}$ and diacylglycerol was crucial for TLQP-21 bioactivity. In conclusion, our results suggest that the receptor stimulated by TLQP21 belongs to the family of the $G_{q}$-coupled receptors, and its activation first increases membrane-lipid derived second messengers which thereby induce the mobilization of $\mathrm{Ca}^{2+}$ from the endoplasmic reticulum followed by a slower store-operated $\mathrm{Ca}^{2+}$ entry from outside the cell.

Keywords: TLQP-21, VGF, calcium, SOCE, STIM-1, receptor, CHO, HFHH-10 


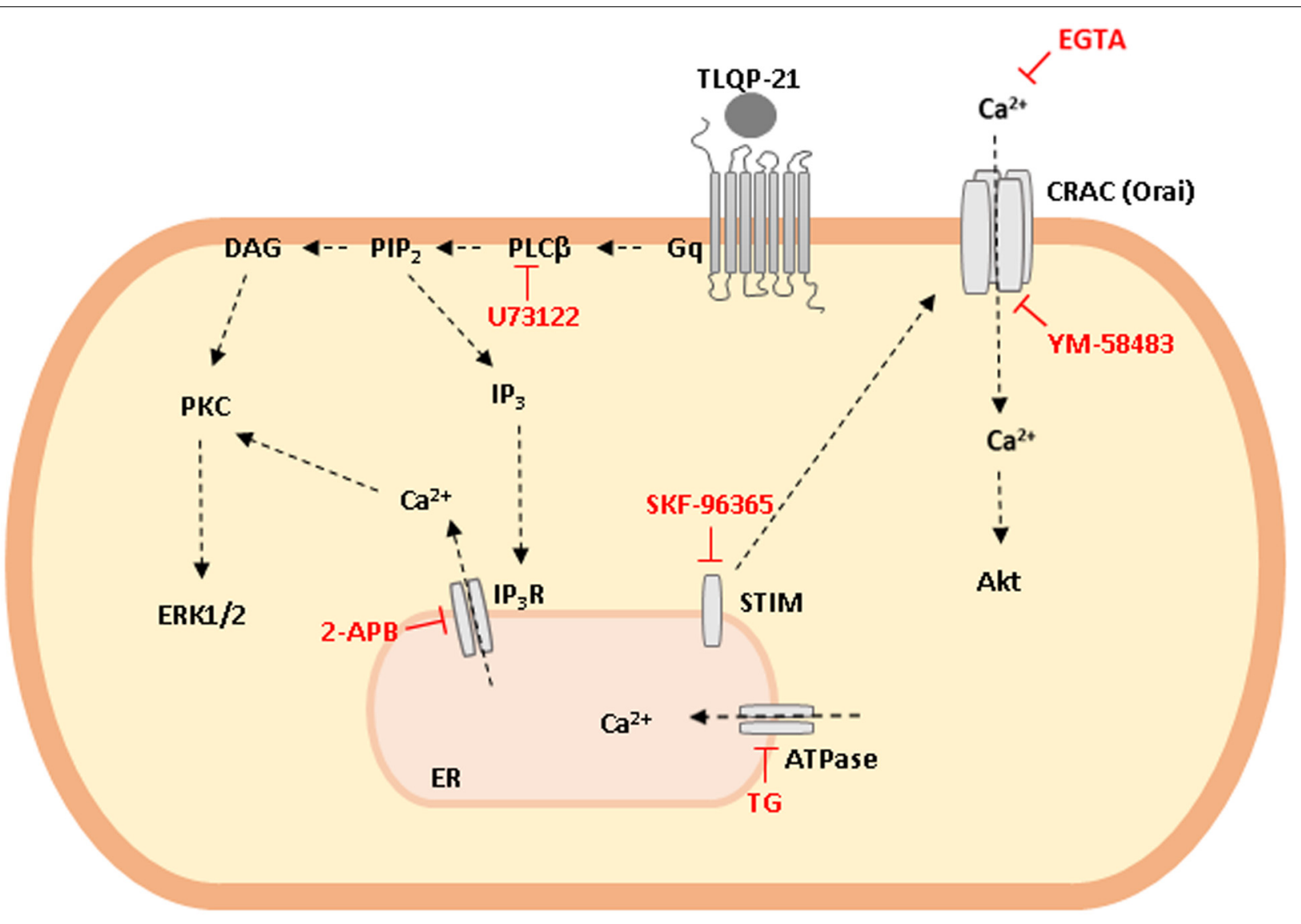

Graphical Abstract | Schematic representation of TLQP-21 intracellular transduction mechanism in CHO cells. TLQP-21, by binding a G protein coupled receptor (GPCR), activates PLC $\beta$ that in turn produces DAG and $\mathrm{IP}_{3}$ as second messengers. These molecules activate PKC, stimulate ERK1/2 phosphorylation and induce intracellular $\mathrm{Ca}^{2+}$ release from the ER with the subsequent $\mathrm{Ca}^{2+}$ entry from outside the cell. Phosphorylation of AKT is probably a result of the increase in cellular $\mathrm{Ca}^{2+}$ concentrations.

\section{INTRODUCTION}

The vgf gene, originally identified as a nerve growth factor responsive gene in PC12 cells (Levi et al., 1985), has a tissuespecific pattern of expression limited to specific neurons and to specific endocrine cells (Salton et al., 2000; Levi et al., 2004). In rodents, the $v g f$ gene encodes a 617 amino acid protein which is included in the extended granin family and is named secretogranin VII (Bartolomucci et al., 2006). Secretogranin VII itself is proteolytically processed to yield more than ten different bioactive peptides (Trani et al., 2002). In the rat brain, VGF is expressed in areas involved in the regulation of feeding, reproduction, stress responsiveness and general homeostasis (Salton et al., 2000; Levi et al., 2004; Razzoli et al., 2012), and VGF-derived peptides have been found significantly decreased in some neurodegenerative diseases (Carrette et al., 2003; Ruetschi et al., 2005; Cocco et al., 2010). VGF immunoreactivity was, as well, reported in gonadotroph and lactotroph cells in the rat anterior pituitary (Ferri et al., 1995).

Among several bioactive peptides derived from VGF, TLQP$21\left(\mathrm{VGF}^{556-576}\right)$ is a 21 amino acid peptide which has been immunopurified from brain tissues (Bartolomucci et al., 2006).
Despite many efforts to characterize the physiological effects of TLQP-21, little is known about its molecular targets. Nonetheless, adipocytes express a high affinity binding site for TLQP-21 and in these cells TLQP-21 stimulates a pro-lipolytic effect (Possenti et al., 2012). Moreover, we have recently demonstrated TLQP21 binding sites on $\mathrm{CHO}$ cells through the use of Atomic Force Microscopy (Cassina et al., 2013). Interestingly, the rat ovary express high levels of TLQP-21, which has been proposed to affect female reproduction by modulating pituitary LH release (Aguilar et al., 2013; Noli et al., 2014) The statistical distribution of the attractive force between TLQP-21 and its binding site is indicative of a single class of binding sites. This presence of a TLQP-21 binding site in these cells is consistent with their unique dose- and time-dependent increases of intracellular calcium $\left(\mathrm{Ca}^{2+}\right.$ ) mobilization in response to TLQP-21 (Cassina et al., 2013). TLQP-21 stimulation of intracellular $\mathrm{Ca}^{2+}$ was concentration-dependent, whereas LRPS-21 (a scrambled control peptide that contains the same amino acids residues of TLQP21 but rearranged in a random order to prevent homology with other published proteins) did not stimulate $\mathrm{Ca}^{2+}$ increases in CHO cells, confirming the specificity of TLQP-21 effects. Furthermore, N38 cells, which do not respond to TLQP-21, 
do not express binding sites for TLQP-21 in the Atomic Force Microscopy measurements (Cassina et al., 2013).

It has recently been proposed that the complement component 3a receptor 1 (C3aR1) mediates TLQP-21 signaling in CHO cells, and that TLQP-21 could be a natural agonist of this receptor (Hannedouche et al., 2013). Noteworthy, it has been reported that the stimulation of CHO cells with TLQP-21 did not induce any measurable intracellular $\mathrm{Ca}^{2+}$ increase unless cells were subjected to a strong priming with $100 \mu \mathrm{M}$ ATP (Hannedouche et al., 2013). Other authors have also reported that in rat macrophages TLQP-21 binds specifically to the complement component $\mathrm{Clq}$ receptor $(\mathrm{gClqR})$ (Chen et al., 2013). Interestingly, gC1qR and C3aR1 are receptors for complement protein and it is possible that TLQP-21 interacts with both receptors; however, which receptor mediates the effects of TLQP-21 is still object of debate.

Since TLQP-21 is emerging as a novel target for obesityassociated disorders (Bartolomucci et al., 2006; Possenti et al., 2012), diabetes (Stephens et al., 2012), neuropathic pain (Chen et al., 2013; Fairbanks et al., 2014) and other human pathologies (Cocco et al., 2010), the purpose of this study was to better characterize the binding site for TLQP-21 in CHO cells, investigating its binding characteristics and the intracellular pathways activated by the peptide-receptor interaction. The data presented here clearly indicate that TLQP-21 binds to a single class of receptors, probably belonging to the family of the $\mathrm{G}_{\mathrm{q}}$-coupled receptors, and stimulates intracellular $\mathrm{Ca}^{2+}$ release primarily from the endoplasmic reticulum (ER).

\section{MATERIALS AND METHODS}

\section{Chemicals}

TLQP-21 (TLQPPASSRRRHFHHALPPAR), YATL-23 (YATLQ PPASSRRHFHHALPPAR), TLQP-62 (TLQPPASSRRRHFHHA LPPARHHPDLEAQARRAQEEADAEERRLQEQEELEN-YIEH VLLHRP), TLQP-8 (TLQPPASS), HFHH-10 (HFHHALPP AR), HHPD-41 (HHPDLEAQARRAQEEADAEERRLQEQEELE NYIEHVLLHRP), and LRPS-21 (LRPSHTRPAHQSFARP LHRPA) have been synthesized by us using conventional solid phase synthesis.

Cyclosporine A (CsA), thapsigargin (TG), U73122, 2Aminoethyl diphenylborinate (2-APB), SKF-96365, YM-58483, and EGTA were purchased from Sigma-Aldrich (St Louis, MO, USA). Unless otherwise specified, all other reagents were from Sigma-Aldrich.

\section{Cell Cultures}

CHO cells were cultured in HAM'S F12 medium supplemented with $10 \%$ heat-inactivated foetal bovine serum (FBS), $100 \mathrm{IU} / \mathrm{ml}$ penicillin, $100 \mu \mathrm{g} / \mathrm{ml}$ streptomycin, and $2 \mathrm{mM} \mathrm{L}$-glutamine (all Euroclone, Pero, Italy) under standard cell culture conditions (at $37^{\circ} \mathrm{C}$, in $5 \% \mathrm{CO}_{2}$ ).

\section{Intracellular $\mathrm{Ca}^{2+}$ Mobilization Assay}

$\mathrm{CHO}$ cells were plated at 20.000 cells/well into black walled, clear bottom 96-well plate (Corning, Germany) and cultured one day up to $80-90 \%$ of confluence. Prior to assay, cells were incubated in dark conditions with $100 \mu \mathrm{l}$ of Hank's Balanced Salt Solution (HBSS) containing $20 \mathrm{mM}$ HEPES, $2.5 \mathrm{mM}$ probenecid and $4.5 \mu \mathrm{M}$ FLUO-4 NW (Molecular Probes, Eugene, OR, USA) at $37^{\circ} \mathrm{C}$ and $5 \% \mathrm{CO}_{2}$ for $45 \mathrm{~min}$. Fluorescence emissions were measured with the multilabel spectrophotometer VICTOR ${ }^{3}$ (Perkin Elmer, MA, USA) at $485 / 535 \mathrm{~nm}$ (excitation/emission filters) every $0.5 \mathrm{~s}$ for the $20 \mathrm{~s}$ preceding and the $60 \mathrm{~s}$ following the stimulation. TLQP21, TLQP-62, TLQP-8, HHPD-41, HFHH-10, and LRPS-21 were diluted in HBSS solution and injected into the wells by an automated injector system. The nature of $\mathrm{Ca}^{2+}$ stores involved in TLQP-21 action was investigated preincubating cells with TG $(2 \mu \mathrm{M}, 20 \mathrm{~min})$, an inhibitor of the $\mathrm{Ca}^{2+}$ ATPase pump responsible for sequestering $\mathrm{Ca}^{2+}$ in the ER (Feng et al., 2008), or CsA ( $2 \mu \mathrm{M}, 15 \mathrm{~min}$ ), an inhibitor of the mitochondrial permeability transition pore (PTP) (Liantonio et al., 2007). To ascertain whether phospholipase C (PLC) and inositol trisphosphate receptors $\left(\mathrm{IP}_{3} \mathrm{R}\right)$ were involved in TLQP21 mechanism of action, cells were incubated with a specific PLC inhibitor (U73122, $10 \mu \mathrm{M}$ for $10 \mathrm{~min}$ ) and a $\mathrm{IP}_{3} \mathrm{R}$ antagonist (2-APB, $75 \mu \mathrm{M}$ for $15 \mathrm{~min}$ ) before the injection of TLQP-21 (Macmillan and McCarron, 2010; Li et al., 2013). Depletion of $\mathrm{Ca}^{2+}$ from the ER leads to $\mathrm{Ca}^{2+}$ entry from outside the cell by activation of Store-Operated Channels (SOCs). Again, to assess the involvement of this pathway, $\mathrm{CHO}$ cells were incubated with selective antagonists of this pathway (SKF-96365 and YM-58483 $10 \mu \mathrm{M}$ for $20 \mathrm{~min}$, EGTA $1 \mathrm{mM}$ for $30 \mathrm{~min}$ ) before the injection of TLQP-21 (Ishikawa et al., 2003; Li et al., 2013).

\section{TLQP-21 Binding Assay}

Binding of TLQP-21 to crude membranes $(30,000 \times g$ pellet) obtained from $\mathrm{CHO}$ cells was carried out using $\left[{ }^{125} \mathrm{I}\right]-$ YATL-23 as ligand. YATL-23 was radioiodinated (specific activity, $2000 \mathrm{Ci} / \mathrm{mmol}$ ) using the lactoperoxidase method (Muccioli et al., 1998; Muccioli et al., 2001) by Perkin Elmer (Milan, Italy) and purified by reverse phase highperformance liquid chromatography. For the single point binding assay, cell membranes (corresponding to $100 \mu \mathrm{g}$ membrane protein) were incubated in triplicate at $23^{\circ} \mathrm{C}$, unless otherwise noted, for $4 \mathrm{~h}$ under constant shaking with $0.5 \mathrm{nM}\left[{ }^{125} \mathrm{I}\right]-Y A T L-23$ in a final volume of $0.5 \mathrm{ml}$ assay buffer (50 mM Tris, $2.5 \mathrm{mM}$ EGTA, $0.002 \%$ bacitracin, $0.1 \%$ bovine serum albumin, titrated to a final $\mathrm{pH}$ of 7.4 with $\mathrm{HCl}$ ). Non-specific binding was measured in parallel incubations with $1 \mu \mathrm{M}$ unlabelled YATL-23 to displace the radioligand. Similar results were obtained using TLQP21 to displace the radioligand. The binding reaction was terminated by the addition of ice-cold assay buffer, followed by rapid filtration through Whatman GF/B filters as previously reported (Muccioli et al., 1998) and the radioactivity bound to membranes was measured by a Packard auto- $\gamma$-counter. Specific binding-values were calculated as the difference obtained subtracting non-specific from total binding. Specific binding was expressed as a percentage of the total radioactivity added. For saturation binding studies, cell membranes were 
incubated with various concentrations of the radioligand (0.03$4 \mathrm{nM})$. Competition studies were performed by incubating cell membranes (150 $\mu \mathrm{g} /$ tube) with $1 \mathrm{nM}\left[{ }^{125} \mathrm{I}\right]-Y A T L-23$ with or without various concentrations (from $10 \mathrm{pM}$ to $0.1 \mu \mathrm{M}$ ) of unlabelled YATL-23, TLQP-21, or LRPS-21. Data were plotted and curves fit using the GraphPad Prism software version 4 (GraphPad Software, San Diego, CA, USA) assuming that the binding was due to a single class of binding sites, thus allowing determination of the maximum binding capacity $\left(\mathrm{B}_{\max }\right)$, dissociation constant $\left(\mathrm{K}_{\mathrm{d}}\right)$, Hill slope and concentration of the competitor causing $50 \%$ inhibition $\left(\mathrm{IC}_{50}\right)$ of specific radioligand binding.

\section{Phosphorylation of Cellular Kinases}

$\mathrm{CHO}$ cells were plated $24 \mathrm{~h}$ before time course experiments in $35 \mathrm{~mm}$ dishes at $70 \%$ confluence. After three washes with medium w/o serum, cells were serum-starved for $1 \mathrm{~h}$. Time course experiments were performed and after quick removal of the medium the reaction was stopped by placing the dish on ice and adding $100 \mu \mathrm{l}$ of ice-cold lysis buffer (50 mM Tris- $\mathrm{HCl}, \mathrm{pH}$ $7.5,150 \mathrm{mM} \mathrm{NaCl}, 10 \mathrm{mM}$ EDTA) containing a protease inhibitor cocktail and PhosphoStop inhibitor cocktail (Roche Diagnostic, Mannheim, Germany).

Cells were stored at $-80^{\circ} \mathrm{C}$ until further processing. Cells were harvested and equivalent amounts of cell extracts (corresponding to approximately 200.000 cells) were run on NuPAGE precast $4-12 \%$ gradient gels (Invitrogen, USA) and transferred to a polyvinylidene difluoride (PVDF) membrane (Amersham). After staining with Ponceau $S$ to verify uniformity of protein load/transfer, membranes were analyzed for immunoreactivity. Incubation with primary antibodies (anti-phospho-AMPK (Thr172); anti-phospho-AKT (Ser473); anti-phospho-ERK1/2 (Thr202/Tyr204); anti-phospho-PKC (Ser660); anti-phospho-PLA2 (Ser505); anti-phospho-JNK (Ser63); and anti-phospho-PLC $\gamma 1$ (Tyr783) rabbit polyclonal antibodies; Cell Signaling Technology, Danvers, MA, USA) at 1:1.000 dilution was performed overnight at $4^{\circ} \mathrm{C}$ (Petrocchi et al., 2010). Incubation with peroxidase-coupled secondary antibodies (Amersham, Arlington Heights, IL, USA; now GE; 1:5.000) was performed for $1 \mathrm{~h}$ at room temperature. Immunoreactivity was developed by enhanced chemiluminescence (ECL system; Amersham GE Healthcare, UK). Two parallel gels were run for each experiment and with probes for different antiphosphorylated protein antibodies as indicated, avoiding stripping protocols. The gels were normalized with anti- $\beta$-actin monoclonal antibodies (Sigma). $\beta$-actin was chosen since we have previously observed that its levels remained stable in time, wherease those of $\alpha$-tubulin decreased over time (Petrocchi et al., 2010).

\section{Statistical Analysis}

Values are expressed as mean \pm SEM. The statistical significance of differences between groups was evaluated with TukeyKramer's t-test for multiple comparisons, preceded by the analysis of variance (ANOVA). Where appropriate, F-values and degrees of freedom (DF) are indicated in the legend of figures. A P-value of less than 0.05 was considered significant.

\section{RESULTS}

\section{TLQP-21 Stimulates Intracellular $\mathbf{C a}^{2+}$ Levels in CHO Cells}

$\mathrm{CHO}$ cells were incubated in vitro with increasing concentrations (1 nM-10 $\mu \mathrm{M})$ of TLQP-21. TLQP-21 (0.1 $\mu \mathrm{M}-10 \mu \mathrm{M})$ evoked acute and significant increases $(P<0.05)$ in intracellular $\mathrm{Ca}^{2+}$ levels in CHO cells (Figure 1A); by comparison, LRPS-21 tested at the concentration interval of $1 \mathrm{nM}-10 \mu \mathrm{M}$ did not stimulate $\mathrm{Ca}^{2+}$ levels in $\mathrm{CHO}$ cells (Figure 1A) thereby confirming the specificity of TLQP-21 action.

In the next series of experiments, we investigated whether $\mathrm{CHO}$ cells could respond to repeated TLQP-21 stimulations given at $5 \mathrm{~min}$ intervals from each other. Levels of free intracellular $\mathrm{Ca}^{2+}$ increased sharply upon the first challenge with $10 \mu \mathrm{M}$ TLQP-21, whereas 5 min later a second application of $10 \mu \mathrm{M}$ TLQP-21 induced only a blunted increase in cell fluorescence; no effects were observed when 5 min later $10 \mu \mathrm{M}$ TLQP-21 was applied a third time (Figure 1B). A final challenge with $10 \mu \mathrm{M}$ ATP to check for cell viability was not affected (data not shown).

\section{Calcium Mobilizing Effects of VGF-Derived Peptides}

To gain further insight into the biological activity of VGFderived peptides, we stimulated $\mathrm{CHO}$ cells with different peptides derived from the C-terminal region of VGF (Table 1). Natural processing of TLQP-62 by prohormone convertases yields TLQP-21 and HHPD-41 (Table 1). The $1 \mu \mathrm{M}$ concentration has been chosen to compare the effects of TLQP-62 and its fragments on intracellular $\mathrm{Ca}^{2+}$ levels since this concentration was close to the EC50 of TLQP-21 and could have allowed to measure whether a test compound was less or more active than TLQP-21. At concentrations as large as $1 \mu \mathrm{M}$ TLQP62 failed to stimulate any significant increase in intracellular $\mathrm{Ca}^{2+}$ levels (Figure 2). Similarly, HHPD-41 was also ineffective, whereas TLQP-21 significantly stimulated intracellular calcium mobilization (Figure 2). TLQP-21 itself is a substrate for prohormone convertases to yield TLQP-8 (8 amino acids at the N-terminal of TLQP-21) and HFHH-10 (10 amino acids at the C-terminal of TLQP-21). HFHH-10 effectively stimulated an intracellular $\mathrm{Ca}^{2+}$ increase in CHO cells; by comparison, TLQP8 at $1 \mu \mathrm{M}$ induced only a slight and non-significant increase in intracellular $\mathrm{Ca}^{2+}$. These results strongly suggest that the C-terminal region of TLQP-21 is the sequence primarily involved in the stimulation of its receptor on CHO cells (Figure 2).

\section{TLQP-21 Binding Analysis in CHO Cells}

The addition of Tyr-Ala (YA) amino acidic residues to TLQP-21 resulted in a peptide (YATL-23) with the same in vitro biological activity of TLQP-21 in CHO cells (data not shown).

Given the evidence of intracellular $\mathrm{Ca}^{2+}$ mobilization induced by TLQP-21 in CHO cells, we investigated the presence of specific TLQP-21 binding sites on CHO cell membranes by radioreceptor assay using $\left[{ }^{125} \mathrm{I}\right]$-YATL-23 as a ligand. The specific binding of $\left[{ }^{125} \mathrm{I}\right]$-YATL-23 to cell membranes varied with both incubation time and temperature. Specific binding increased 
A

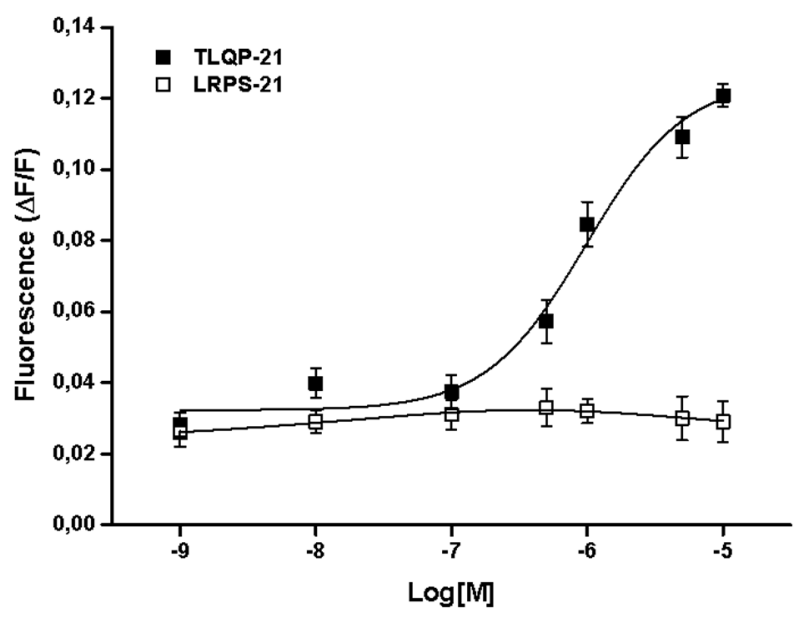

B

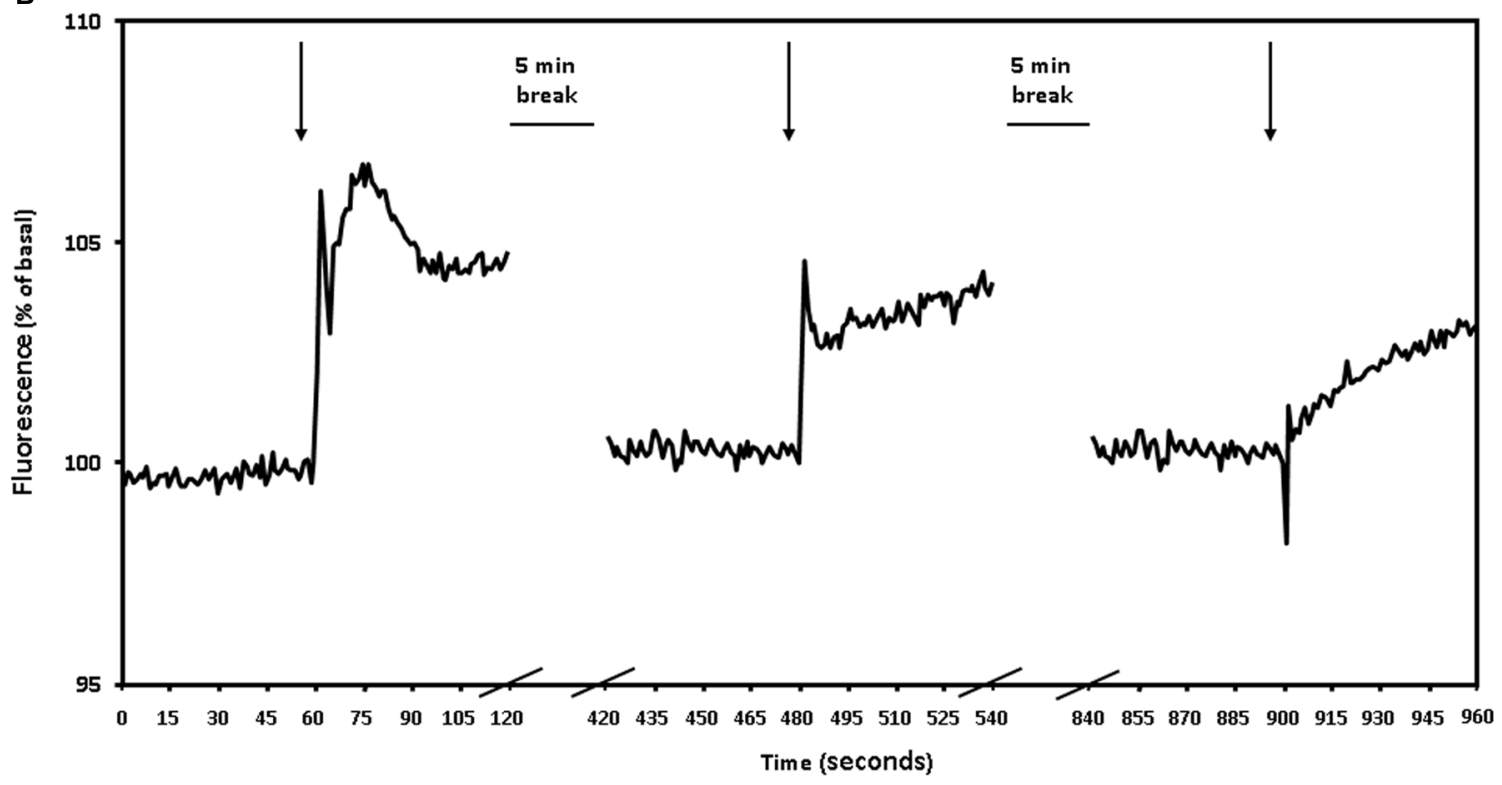

FIGURE 1 | TLQP-21 stimulation of intracellular $\mathrm{Ca}^{2+}$ levels in CHO cells. (A) Cells were loaded with FLUO-4 NW and fluorescence emissions were measured at $485 / 535 \mathrm{~nm}$ (excitation/emission filters) every $0.5 \mathrm{~s}$ for the $60 \mathrm{~s}$ following injection of the stimuli. TLQP-21 was applied at concentrations ranging from $1 \mathrm{nM}$ to $10 \mu \mathrm{M} . \mathrm{Ca}^{2+}$ mobilizing activity of TLQP-21 is plotted in terms of maximal response obtained at each given concentration in $\mathrm{CHO}$ cells. To ascertain the specificity of the effects, cells were also challenged with $1 \mathrm{nM}-10 \mu \mathrm{M}$ LRPS-21, a scrambled peptide containing the same amino acid residues of TLQP-21. (B) Effects of repeated stimulation with TLQP-21 on intracellular $\mathrm{Ca}^{2+}$ levels in $\mathrm{CHO}$ cells. $10 \mu \mathrm{M}$ TLQP-21 was applied three times at 5 min intervals. Fluorescence was recorded every $0.5 \mathrm{~s}$. Results are the means \pm SEM of measurements obtained in at least six different wells for each experiment. All experiments have been repeated at least three times.

TABLE 1 | Aminoacidic sequence of peptides of the C-terminal region of VGF.

\begin{tabular}{|c|c|}
\hline & VGF-derived peptides \\
\hline TLQP-62 & TLQPPASSRRRHFHHALPPAR|HHPDLEAQARRAQEEADAEERRLQEQEELENYIEHVLLHRP \\
\hline TLQP-21 & TLQPPASSRRR'HFHHALPPAR \\
\hline HHPD-41 & 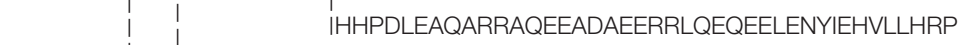 \\
\hline TLQP-8 & TLQPPASS \\
\hline HFHH-10 & HFHHALPPAR \\
\hline
\end{tabular}

TLQP-62 is the largest peptide encoded in the C-terminal sequence of VGF. Shorter peptides could be processed from its sequence. Dashed lines indicate the putative sites for endoproteolytic cleavage. 


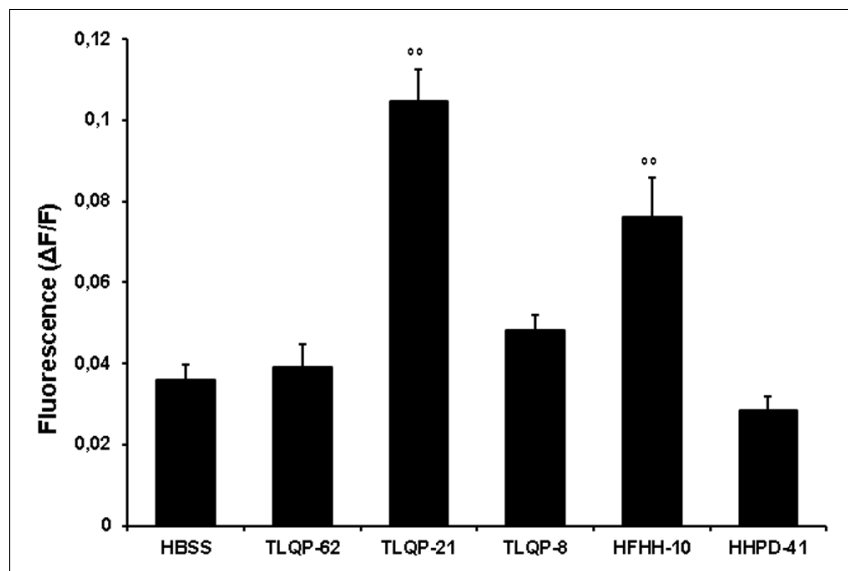

FIGURE 2 | VGF-derived peptides stimulation of intracellular $\mathbf{C a}^{2+}$ levels in $\mathbf{C H O}$ cells. Cells were loaded with FLUO-4 NW and stimulated with different VGF-derived peptides $(1 \mu \mathrm{M}) . \mathrm{Ca}^{2+}$ mobilizing activity of peptides is plotted in terms of maximal response obtained at each given concentration in $\mathrm{CHO}$ cells. Values plotted have been calculated as the difference between stimulated fluorescence and pre-stimulated fluorescence divided by pre-stimulated fluorescence $(\Delta \mathrm{F} / \mathrm{F})$. Results are the means $\pm \mathrm{SEM}$ of measurements obtained in at least five different wells for each experiment. ANOVA: $F=23.3 ; D F=29$. All experiments have been repeated at least three times. ${ }^{\circ} p<0.01$ vs. HBSS

with the duration of incubation and was greater at $23^{\circ} \mathrm{C}$ when compared to $4^{\circ} \mathrm{C}$ after reaching equilibrium at $4 \mathrm{~h}$ (Figure 3A). A study of specific binding as a function of membrane protein concentration indicated that the binding was proportional to protein content up to at least $100 \mu \mathrm{g} /$ tube (Figure 3B). Specific binding of $\left[{ }^{125} \mathrm{I}\right]$-YATL-23 to cell membranes occurred over a relatively wide range of $\mathrm{pH}$. The maximal binding was observed at $\mathrm{pH} 7.4$ and declined to half-maximal value at $\mathrm{pH} 5.0$ and 9.0 (Figure 3C). Therefore, all subsequent incubations were carried out at $\mathrm{pH} 7.4$ for $4 \mathrm{~h}$ at $23^{\circ} \mathrm{C}$ with $100 \mu \mathrm{g}$ membrane protein. Brief exposure of $\mathrm{CHO}$ cell membranes to high temperature $\left(100^{\circ} \mathrm{C} \times 1 \mathrm{~min}\right)$ or enzymes that disrupt protein structure such as trypsin $(50 \mu \mathrm{g} / \mathrm{ml} \times 5 \mathrm{~min})$ caused the loss of the specific binding of $\left[{ }^{125} \mathrm{I}\right]$-YATL-23, suggesting that protein integrity is functionally important in the binding site (Figure 3D).

Experiments using various concentrations of [ $\left.{ }^{125} \mathrm{I}\right]$-YATL23 indicated the presence of a saturable and specific binding associated with minor low non-specific binding (Figure 4A). Scatchard transformation of the specific binding data (Figure 4B) yielded a linear Scatchard plot with Hill slope close to 1 (Figure 4C), indicating the existence of a single class of binding sites. The calculated $K_{\mathrm{d}}$ and $B_{\max }$ values (means \pm SEM of three independent experiments) were $0.55 \pm 0.05 \times 10^{-9} \mathrm{M}$ and $81.7 \pm 3.9 \mathrm{fmol} / \mathrm{mg}$ protein, respectively, and the Hill slope was $1.07 \pm 0.1$.

Unlabelled YATL-23 and TLQP-21 competed in a concentration-dependent manner with $\left[{ }^{125} \mathrm{I}\right]-Y A T L-23$ for binding sites in $\mathrm{CHO}$ membranes (Figure 5). The $\mathrm{IC}_{50}$ values, calculated according a one-site binding model (means \pm SEM of three independent experiments), were $1.2 \pm 0.06 \times 10^{-9} \mathrm{M}$ for YATL-23 and $0.98 \pm 0.06 \times 10^{-9} \mathrm{M}$ for TLQP-21. The results of these competition binding studies also revealed that the binding of $\left[{ }^{125} \mathrm{I}\right]$-YATL-23 to CHO membranes was specific and was not inhibited by LRPS-21, the scrambled peptide made using the same amino acidic residues of TLQP-21 (Figure 5). These findings provide evidence that $\mathrm{CHO}$ cells contain significant amounts of TLQP-21 binding sites showing typical features of ligand-receptor interaction.

\section{Intracellular Transduction Mechanisms Activated by TLQP-21}

It is known that $\mathrm{Ca}^{2+}$ stores, such as ER and mitochondria, dynamically participate in generation of cytoplasmic $\mathrm{Ca}^{2+}$ signals (Verkhratsky and Petersen, 1998). We therefore studied the possible implication of these intracellular organelles in the increase of intracellular $\mathrm{Ca}^{2+}$ levels induced by TLQP-21. The involvement of the ER was investigated using TG, which inhibits the $\mathrm{Ca}^{2+}$-ATPase pump responsible for sequestering $\mathrm{Ca}^{2+}$ in the ER and depletes the store by irreversibly preventing its refilling. As shown in Figure 6A, TG reduced the TLQP-21mediated increase of intracellular $\mathrm{Ca}^{2+}$, causing a $56 \%$ reduction after 20 min preincubation time. To rule out the possibility that $\mathrm{Ca}^{2+}$ release from the mitochondria could also be involved, we evaluated the effect of TLQP-21 in the presence of CsA, an inhibitor of the mitochondrial PTP (Chernyak, 1997). The incubation of $\mathrm{CHO}$ cells with $2 \mu \mathrm{M}$ CsA did not modify the basal levels of intracellular $\mathrm{Ca}^{2+}$ and a subsequent stimulation with $1 \mu \mathrm{M}$ TLQP-21 induced a significant increase in intracellular $\mathrm{Ca}^{2+}$ levels (Figure 6A). These results indicate that TLQP-21 stimulated $\mathrm{Ca}^{2+}$ release primarily from the ER store, whereas release of $\mathrm{Ca}^{2+}$ from the mitochondria appeared not involved in this mechanism of action.

In many cellular systems, PLC activation and subsequent $\mathrm{IP}_{3}$ production is the transduction pathway regulating the release of $\mathrm{Ca}^{2+}$ from ER. U73122 is an aminosteroid that is reported to act as a specific inhibitor of PLC (Bleasdale et al., 1990) and it is widely used as a quick test for the involvement of PLC in a signaling pathway. To test whether TLQP-21 induces $\mathrm{Ca}^{2+}$ mobilization through a PLC-dependent mechanism, CHO cells were incubated for $10 \mathrm{~min}$ with $10 \mu \mathrm{M}$ U73122. Results demonstrate that U73122 induced a dramatic reduction, about $82 \%$, of TLQP-21 stimulation of intracellular $\mathrm{Ca}^{2+}$ mobilization (Figure 6B). As a further confirmation, $\mathrm{CHO}$ cells were pre-incubated for $15 \mathrm{~min}$ with $75 \mu \mathrm{M}$ 2-APB, which rapidly inhibits $\mathrm{IP}_{3} \mathrm{R}$-mediated $\mathrm{Ca}^{2+}$ release. Treatment with 2-APB strongly affect TLQP-21 activity, causing a decrement of intracellular $\mathrm{Ca}^{2+}$ mobilization of about $79 \%$ (Figure 6B). As previously reported, depletion of $\mathrm{Ca}^{2+}$ from the ER causes the activation of stromal interaction molecule (STIM) proteins that, translocating into junctions formed between the ER and the plasma membrane (PM), activate the highly calcium-selective Orai channels to homeostatically balance intracellular calcium (Soboloff et al., 2012). To assess the role of this pathway, CHO cells were pretreated with a STIM-mediated $\mathrm{Ca}^{2+}$ inhibitor (SKF-96365), an inhibitor of Orai channels (YM-58483) or an extracellular $\mathrm{Ca}^{2+}$ chelator (EGTA) before stimulation with $1 \mu \mathrm{M}$ TLQP-21. 
A

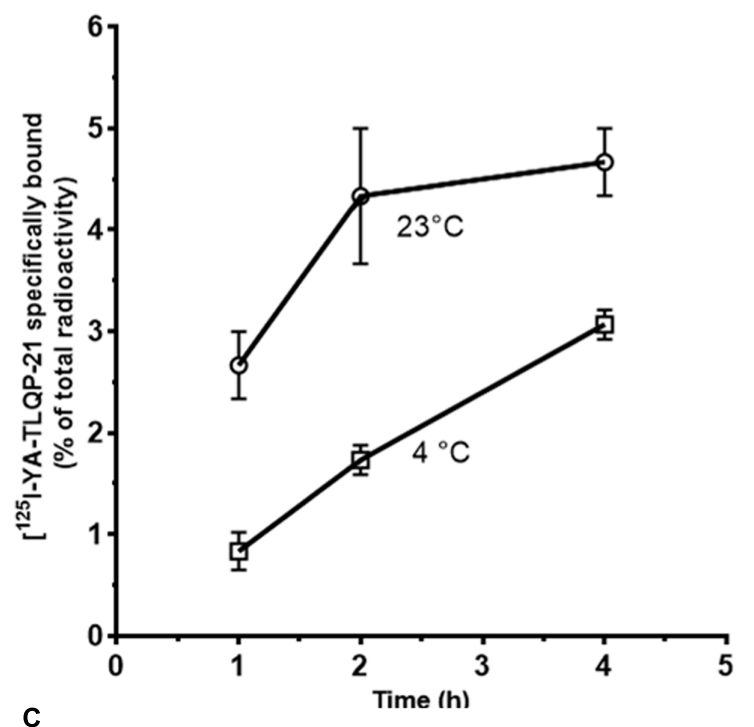

C

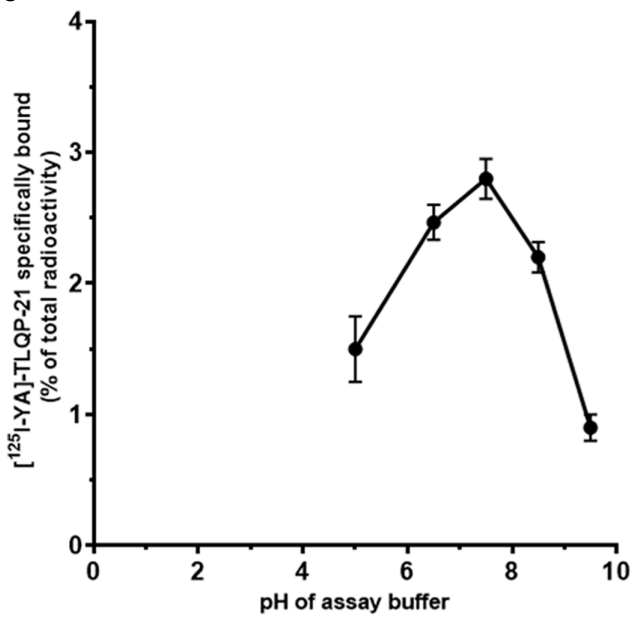

B
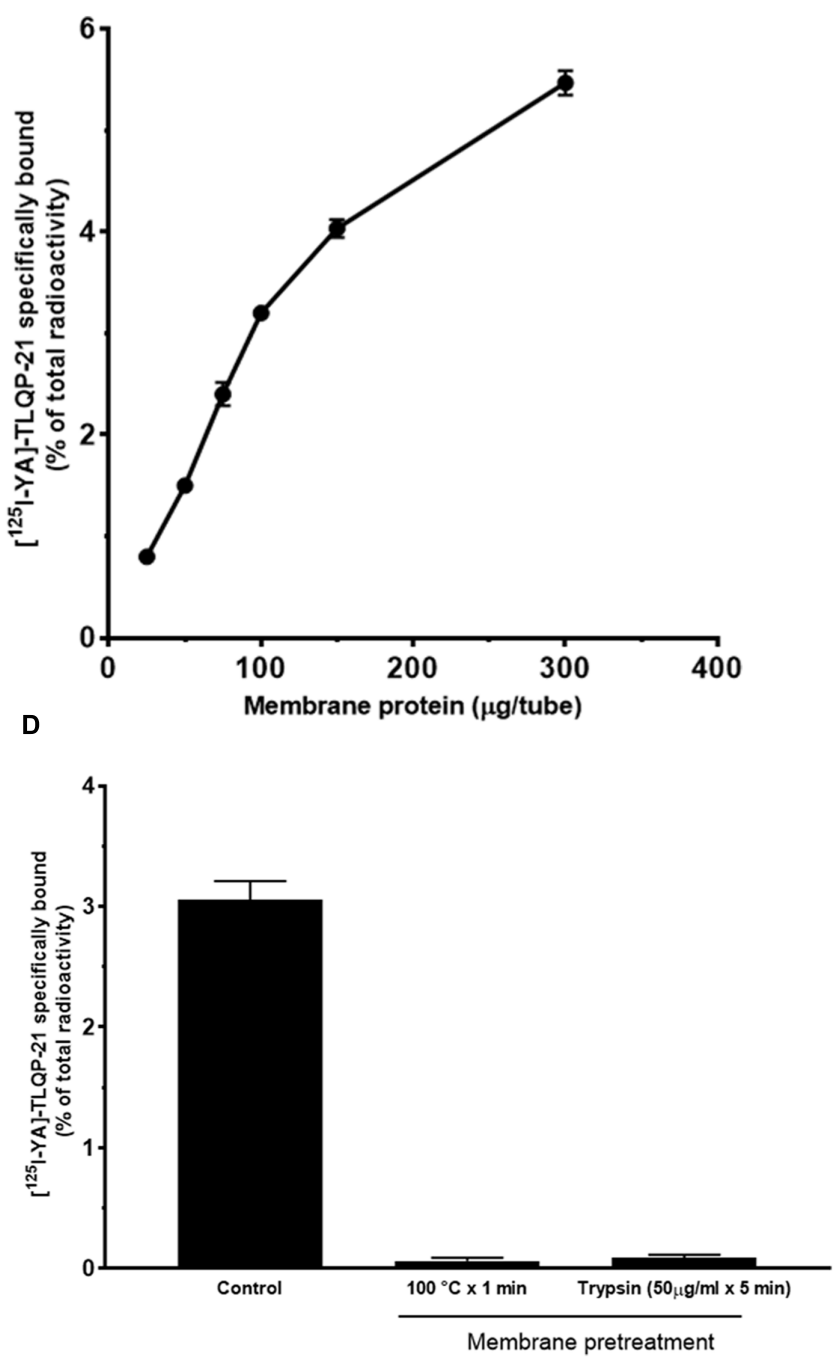

FIGURE 3 | Specific binding of $\left[{ }^{125} \mathrm{I}\right]$-YATL-23 to $\mathrm{CHO}$ cell membranes as a function of the length of assay incubation at $23^{\circ} \mathrm{C}$ or $4^{\circ} \mathrm{C}$ (A), of the amount of membrane protein (B), of $\mathrm{pH}$ of the incubation medium (C) and after membrane treatment at $100^{\circ} \mathrm{C}$ or with trypsin (D). Values are means $\pm \mathrm{SEM}$ of three independent experiments.

We observed a statistically significant decrement in TLQP-21mediated intracellular $\mathrm{Ca}^{2+}$ mobilization (Figure 6C), of about 36,27 , and $45 \%$ after treatment with SKF-96365, YM-58483, and EGTA, respectively.

Next, we measured the effects of TLQP-21 treatment on phosphorylation of intracellular signaling effectors. After $1 \mathrm{~h}$ of serum starvation, cells were exposed to $10 \mu \mathrm{M}$ TLQP-21 for $0-$ $30 \mathrm{~min}$ (Figure 7). The $10 \mu \mathrm{M}$ concentration was chosen because it elicited a stimulation near to maximal on intracellular $\mathrm{Ca}^{2+}$ mobilization (Figure 1). TLQP-21 induced a prompt increase of phospho-AKT (1-5 min) (Figure 7A) that remained significantly higher than basal until 15 min after stimulation (Figure 7A). A rapid and transient dephosphorylation of phospho-AMPK and phospho-PLC $\gamma 1$ occurred between 1 and $10 \mathrm{~min}$ after stimulation with TLQP-21(Figures 7B,C). A similar trend was seen also for phospho-PLA2, but dephosphorylation reached statistical significance only at 2 min (Figure 7D). Interestingly, PKC phosphorylation increased after $2 \mathrm{~min}$ and lasted until 15 min from stimulation with TLQP-21 (Figure 7D). ERK1/2 phosphorylation increased significantly at $2 \mathrm{~min}$, reached a peak at $5 \mathrm{~min}$ and thereafter returned to basal (Figure $7 \mathbf{F}$ ). No effects were induced on phospho-JNK levels (data not shown). A possible limitation of these determinations is that sample loading was normalized using the corresponding $\beta$-actin levels and not the levels of the unphosphorilated protein.

\section{DISCUSSION}

The molecular mechanisms of TLQP-21 action at the cellular level are still an object of debate, although this peptide could 

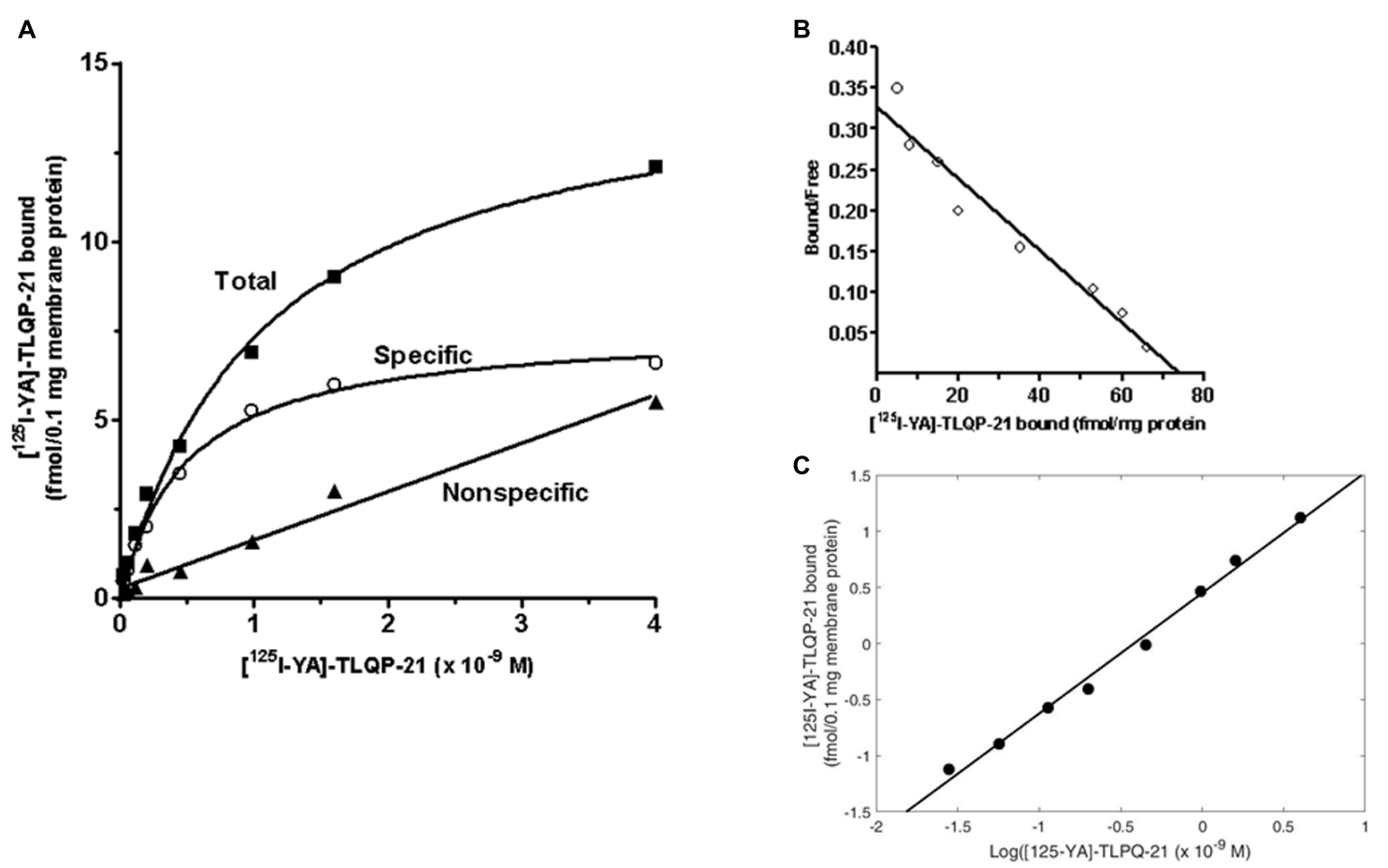

FIGURE 4 | Representative saturation isotherms, Scatchard and Hill plot of [ $\left.{ }^{125} \mathrm{I}\right]-$ YATL-23 binding to $\mathbf{C H O}$ cell membranes. (A) Experiments were performed by incubating a fixed amount of membrane proteins with increasing concentrations of radiolabelled YATL-23, either alone (total binding) or together $1 \mu \mathrm{M}$ unlabelled YATL-23 (nonspecific binding), respectively. Specific binding values were obtained subtracting nonspecific binding from total binding. (B) The saturation curve of specific binding was analyzed by Scatchard analysis. Values of $K_{d}=0.55 \pm 0.05 \times 10^{-9} \mathrm{M}$ and $B_{\max }=81.7 \pm 3.9$ fmol/mg protein were calculated using data obtained in three independent experiments. (C) Hill plot of the same data. The calculated Hill slope of $1.07 \pm 0.1$ is indicative of a single class of binding sites.

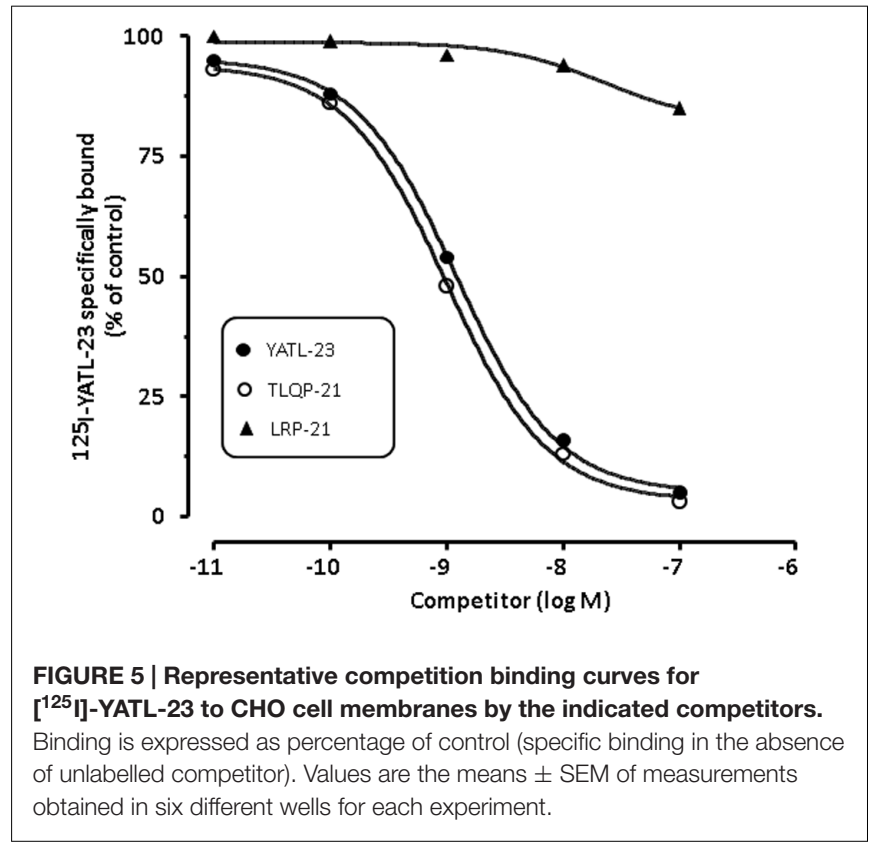

represent an important target to counteract human disorders, including obesity and diabetes. Our results demonstrate that TLQP-21 is a robust extracellular signal capable of promoting a $\mathrm{Ca}^{2+}$-mediated transduction signal in CHO cells. TLQP-21 is one of many bioactive products derived from post-translational cleavage of the C-terminal region of VGF, a propeptide that could be involved in psychiatric, neurologic and metabolic disorders (Carrette et al., 2003; Ruetschi et al., 2005; Bartolomucci et al., 2011; Busse et al., 2012). Although TLQP-21 has been implicated in the regulation of energy balance, nociception, gastric function, and several other physiologic functions, its binding site and mechanisms of action remain largely unknown (Bartolomucci et al., 2006; Rizzi et al., 2008; Chen et al., 2013). We have investigated the ability of some VGF-derived peptides to induce intracellular $\mathrm{Ca}^{2+}$ mobilization in $\mathrm{CHO}$ cells. Our results show that: (i) TLQP-21 stimulates a sharp increase in free intracellular $\mathrm{Ca}^{2+}$ levels; (ii) on this pathway it is more active than other VGF-derived peptides; and (iii) its C-terminal fragment, that corresponds to HFHH-10 peptide, is the region primarily involved in the process of stimulating intracellular $\mathrm{Ca}^{2+}$ mobilization. These results are consistent with those indicating that the "hot spots" for TLQP-21 activity are localized in its C-terminal region (Cero et al., 2014). The $\mathrm{N}$-terminal region of the peptide appears more tolerant to modifications, since the introduction of Tyr-Ala (YA) amino acidic residues (YATL-23) did not change the activity on intracellular $\mathrm{Ca}^{2+}$ mobilization and the ability of the peptide to bind the receptor. However, the N-terminal region of TLQP-21, corresponding to the sequence of TLQP-8, is apparently devoid 

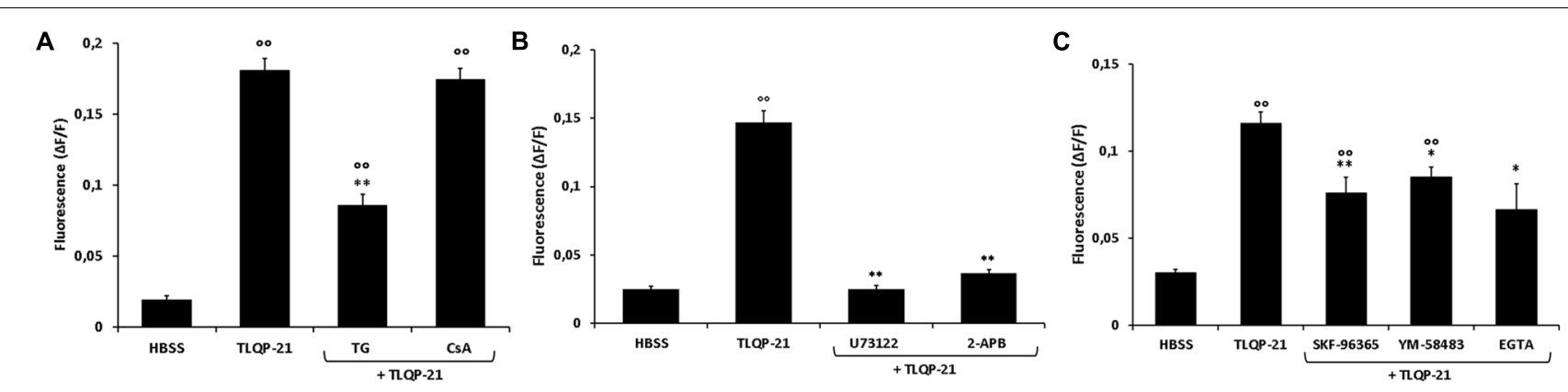

FIGURE 6 | Modulation of intracellular $\mathrm{Ca}^{2+}$ levels by TLQP-21 in the presence of different inhibitors in CHO cells. Cells were loaded with FLUO-4 NW and treated with different inhibitors before the stimulation with $1 \mu \mathrm{M}$ TLQP-21. (A) CsA ( $2 \mu \mathrm{M}, 15 \mathrm{~min})$, a mitochondrial PTP inhibitor, did not affect TLQP-21 Ca ${ }^{2+}$ stimulation as did TG $(2 \mu \mathrm{M}, 20 \mathrm{~min})$, an inhibitor of the ER Ca ${ }^{2+}$-ATPase. ANOVA: $F=23.2$; DF $=46$. (B) The PLC-inhibitor U73122 (10 $\left.\mu \mathrm{M}, 10 \mathrm{~min}\right)$ and the IP ${ }_{3} R$ antagonist 2-APB $(75 \mu \mathrm{M}, 15 \mathrm{~min})$ strongly reduced TLQP-21 stimulation of intracellular $\mathrm{Ca}^{2+}$ mobilization. ANOVA: $F=154.4$; DF $=35$. (C) SKF-96365 (10 $\mu \mathrm{M}$, $20 \mathrm{~min}$ ), YM-58483 (10 $\mu \mathrm{M}, 20 \mathrm{~min})$ and EGTA (1 mM, $30 \mathrm{~min})$, inhibitors of the SOCs pathway, affect significantly TLQP-21 effect. ANOVA: $F=20.4 ;$ DF = 49. Graphs show the means \pm SEM of measurements obtained in at least six different wells for each experiment. All experiments have been repeated at least three times. ${ }^{\circ} p<0.01$ vs. HBSS; ${ }^{*} p<0.05$ and ${ }^{* *} p<0.01$ vs. TLQP-21.

of any activity on intracellular $\mathrm{Ca}^{2+}$ mobilization. Interestingly, molecular dynamics simulations have revealed that TLQP-21 is characterized by a highly flexible nature that fluctuates between many conformations, spanning from a long helical to a more compact form (Chakraborty et al., 2015). Another factor adding complexity to the interpretation of the ability of VGF-derived fragments to activate their receptor is the demonstration that TLQP-21 undergoes a folding-upon-binding transition upon receptor binding (Cero et al., 2014). Further studies are needed to understand whether HFHH-10 satisfies the random coil to helix transitions needed for activating G-protein coupled receptors (Shoichet and Kobilka, 2012).

The results that we have obtained in this research clearly demonstrated that TLQP-21 interacts with a single class of binding site expressed on $\mathrm{CHO}$ cell membranes, further confirming those observations that we have previously reported using Atomic Force Microscopy (Cassina et al., 2013). It is interesting that the membranes of $\mathrm{CHO}$ cells contain significant amounts of TLQP-21 binding sites and this cell line can be a useful in vitro model to study TLQP-21 mechanisms of action. In our setting, TLQP-21 efficiently stimulated intracellular calcium levels in CHO cells without the need of ATP priming previously reported (Hannedouche et al., 2013). $\mathrm{Ca}^{2+}$ is a highly versatile second messenger involved in a variety of intracellular signaling pathways, including gene regulation, proliferation and cell death. Repeated exposure to TLQP-21 resulted in a reduced response, probably indicating a decrease in number of receptors available or a decreased activity of intracellular signaling pathways involved. Interestingly, TLQP-21 induced a specific desensitization to subsequent TLQP-21 treatments, but not to ATP, and these data are consistent with those reported in rat primary macrophages and cerebellar granule cells (Severini et al., 2008; Chen et al., 2013).

We have also shown that TLQP-21 stimulation induced an increase of cytoplasmic $\mathrm{Ca}^{2+}$ levels that was determined by release of $\mathrm{Ca}^{2+}$ from intracellular stores. In particular, our studies indicate that in $\mathrm{CHO}$ cells $\mathrm{Ca}^{2+}$ is released mainly from the ER stores, as demonstrated by the treatment with TG, a $\mathrm{Ca}^{2+}$-ATPase pump inhibitor that depletes the ER store by preventing its refilling (Thastrup et al., 1989), whereas $\mathrm{Ca}^{2+}$ release from the mitochondria did not appear involved. Our results also indicate that $\mathrm{Ca}^{2+}$ mobilization stimulated by TLQP-21 is triggered by the activation of PLC, since pretreatment of the cells with U73122, a known PLC inhibitor, induced a significant reduction of $\mathrm{Ca}^{2+}$ mobilization. Western blotting determinations indicated that TLQP-21 up-regulated the phosphorylation levels of ERK1/2, PKC and AKT in CHO cells. These kinases are activated by the dual phosphorylation of neighboring threonine and tyrosine residues in response to extracellular stimuli (Nadeau and Landry, 2007) Furthermore, our results show that TLQP-21 induced a rapid and transient dephosphorylation of AMPK, PLC $\gamma 1$, and PLA2, whereas the phosphorylation state of JNK was not altered. The intricate balance of phosphorylation by kinases and dephosphorylation by phosphatases is essential for maintaining signal transduction networks in cells (Barford et al., 1998). The rapid increase in the mobilization of intracellular $\mathrm{Ca}^{2+}$ is at least in part dependent on the PLC $\gamma$ family of proteins, including PLC $\gamma 1$ and PLC $\gamma 2$ (Clapham, 2007). It is possible that the dephosphorylation of PLC $\gamma 1$ that we have observed could be involved in the mechanisms by which TLQP-21 induced a clear desensitization to subsequent TLQP-21 treatments. These results suggest that the receptor stimulated by TLQP-21 should belong to the family of the $\mathrm{G}_{\mathrm{q}}$-coupled receptors. It is widely accepted that the $\mathrm{IP}_{3} \mathrm{R}$ on the ER are an essential link between PLC activation and initiation of $\mathrm{Ca}^{2+}$ release from the ER. We have shown that pretreating the $\mathrm{CHO}$ cells with 2 - $\mathrm{APB}$, an $\mathrm{IP}_{3} \mathrm{Rs}$ antagonist, the release of $\mathrm{Ca}^{2+}$ induced by TLQP- 21 was heavily reduced, further confirming that the binding of TLQP21 with its receptor activates the PLC pathway. Reportedly, rapid $\mathrm{Ca}^{2+}$ depletion from the ER activates slower $\mathrm{Ca}^{2+}$ entry from outside the cell (Hewavitharana et al., 2007). STIM and Orai proteins are required for the store-operated $\mathrm{Ca}^{2+}$ entry process (Liou et al., 2005; Roos et al., 2005). Consistently, we have 

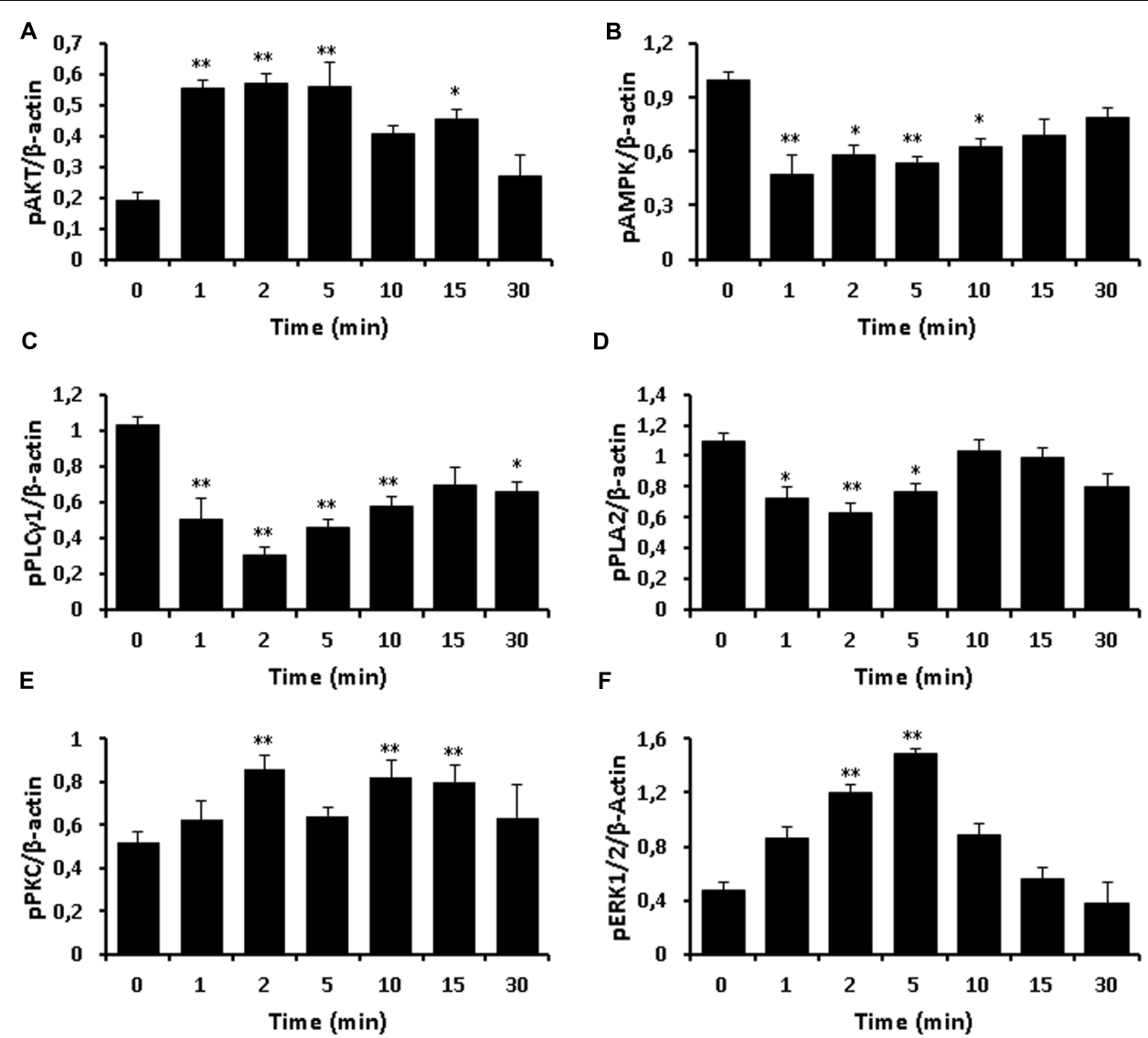

$\mathbf{G}$
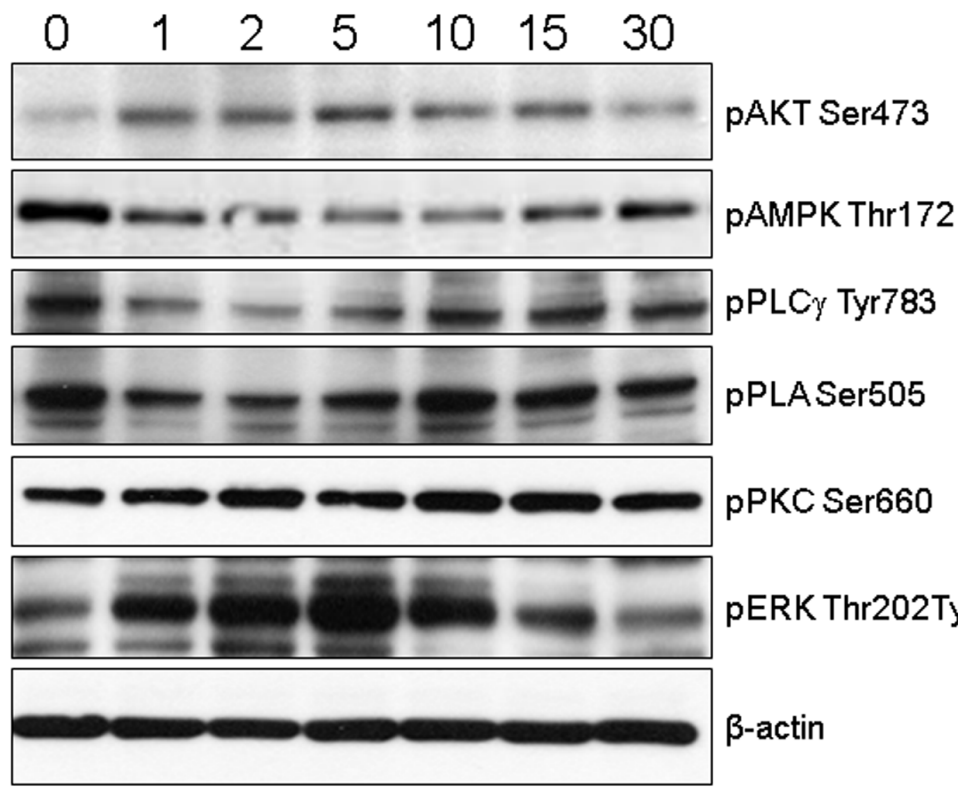

pERK Thr202Tyr204

$\beta$-actin

FIGURE 7 | Western blot analysis of signaling phospho-activated proteins. Time course of $10 \mu \mathrm{M}$ TLQP-21 treatment from 1 min up to 30 min. Equal amounts of cell lysates were processed for Western blot analysis, using specific antibodies for the phosphorylated (active) forms of signaling molecules.

Abbreviations: pAMPK = phospho-AMPK (Thr172); pAKT = phospho-AKT (Ser473); pERK1/2 = phospho-ERK1/2 (Thr202/Tyr204); pPKC = phospho-PKC (Ser660); pPLA2 = phospho-PLA2 (Ser505); and pPLC $\gamma 1=$ phospho-PLC $\gamma 1$ (Tyr783). To ensure equal loading, blots were also probed with anti- $\beta$-actin. (A-F) Results shown are means \pm SEM of at least five measurements obtained in five independent experiments. ${ }^{*} p<0.05$ and ${ }^{* *} p<0.01$ vs. time 0 . (G) representative images of the blots. 
found an inhibition of TLQP-21-mediated $\mathrm{Ca}^{2+}$ release following treatment with SKF-96365 and YM-58483, two specific STIMand Orai-inhibitors, respectively. PLC activation by TLQP-21 is followed by an increase of PKC phosphorylation and, afterwards, ERK1/2 phosphorylation.

Given the previous identification of two putative receptors for TLQP-21, the C3aR1 in CHO and RAW264.7 cells, and the $\mathrm{gC1qR}$ in rat brain membranes, primary microglia, macrophages, and DRG neurons (Chen et al., 2013; Hannedouche et al., 2013), we have attempted its pharmacological characterization in $\mathrm{CHO}$ cells. We have also previously demonstrated the existence of a high-affinity binding site for TLQP-21 in white and brown adipocyte membranes, and adrenals, whose exact nature remains still unknown (Possenti et al., 2012). $\mathrm{CHO}$ cells could be a useful in vitro model to study the interaction of VGF-derived peptides with a putative specific binding site, but the possibility that different binding sites could be expressed by other cell systems cannot be ruled out. Understanding the mechanism of action of TLQP-21 could be of great relevance since this neuropeptide is purported to play important roles in the central nervous system and peripheral tissues.

\section{CONCLUSION}

Our results suggest that TLQP-21 effects in CHO cells could be mediated by a $\mathrm{G}_{\mathrm{q}}$-coupled receptor that quickly activates PLC $\beta$, that produces DAG and $\mathrm{IP}_{3}$ as second messengers. DAG activates PKC that, in turn, stimulates ERK1/2 phosphorylation. On the other hand, by binding $\mathrm{IP}_{3} \mathrm{R}$ on the $\mathrm{ER}, \mathrm{IP}_{3}$ stimulates a sharp

\section{REFERENCES}

Aguilar, E., Pineda, R., Gaytan, F., Sanchez-Garrido, M. A., Romero, M., RomeroRuiz, A., et al. (2013). Characterization of the reproductive effects of the Vgf-derived peptide TLQP-21 in female rats: in vivo and in vitro studies. Neuroendocrinology 98, 38-50. doi: 10.1159/000350323

Barford, D., Das, A. K., and Egloff, M. P. (1998). The structure and mechanism of protein phosphatases: insights into catalysis and regulation. Annu. Rev. Biophys. Biomol. Struct. 27, 133-164. doi: 10.1146/annurev.biophys.27.1.133

Bartolomucci, A., La Corte, G., Possenti, R., Locatelli, V., Rigamonti, A. E., Torsello, A., et al. (2006). TLQP-21, a VGF-derived peptide, increases energy expenditure and prevents the early phase of diet-induced obesity. Proc. Natl. Acad. Sci. U.S.A. 103, 14584-14589. doi: 10.1073/pnas.06061 02103

Bartolomucci, A., Possenti, R., Mahata, S. K., Fischer-Colbrie, R., Loh, Y. P., and Salton, S. R. (2011). The extended granin family: structure, function, and biomedical implications. Endocr. Rev. 32, 755-797. doi: 10.1210/er.2010-0027

Bleasdale, J. E., Thakur, N. R., Gremban, R. S., Bundy, G. L., Fitzpatrick, F. A., Smith, R. J., et al. (1990). Selective inhibition of receptorcoupled phospholipase C-dependent processes in human platelets and polymorphonuclear neutrophils. J. Pharmacol. Exp. Ther. 255, 756-768.

Busse, S., Bernstein, H. G., Busse, M., Bielau, H., Brisch, R., Mawrin, C., et al. (2012). Reduced density of hypothalamic VGF-immunoreactive neurons in schizophrenia: a potential link to impaired growth factor signaling and energy homeostasis. Eur. Arch. Psychiatry Clin. Neurosci. 262, 365-374. doi: 10.1007/ s00406-011-0282-7

Carrette, O., Demalte, I., Scherl, A., Yalkinoglu, O., Corthals, G., Burkhard, P., et al. (2003). A panel of cerebrospinal fluid potential biomarkers for the diagnosis of Alzheimer's disease. Proteomics 3, 1486-1494. doi: 10.1002/pmic.200300470 increase of intracellular $\mathrm{Ca}^{2+}$ levels and the subsequent $\mathrm{Ca}^{2+}$ entry from outside the cell through STIM-Orai interaction (see Graphical abstract). The $\mathrm{CHO}$ cell line can be proposed as a useful model for developing new synthetic agonists and antagonists of TLQP-21 receptor, which could help a better understanding of the physiologic and pathological role of VGF-derived peptides.

\section{ETHICS STATEMENT}

The study was made in vitro using cell lines only. No experiments were performed on animals or involved human beings. Approval from the local Ethic Committee or other regulatory agencies was not required.

\section{AUTHOR CONTRIBUTIONS}

AT, RP, VL, and RO supervised the entire project, designed research, and wrote the paper. GB and IR conceived and designed the experiments, interpreted and analyzed data, supervised all the experimental procedure. LM, LR, EB, PP, CG, GM, J-AF, $\mathrm{PV}, \mathrm{AB}$, and JM conceived and designed the experiments, performed research, interpreted, and analyzed data. AT, RO, and $\mathrm{VL}$ analyzed data and critically revised the manuscript.

\section{FUNDING}

This work was supported by Fondo di Ateneo per la Ricerca of the University of Milano-Bicocca [FAR to AT and VL].

Cassina, V., Torsello, A., Tempestini, A., Salerno, D., Brogioli, D., Tamiazzo, L., et al. (2013). Biophysical characterization of a binding site for TLQP-21, a naturally occurring peptide which induces resistance to obesity. Biochim. Biophys. Acta 1828, 455-460. doi: 10.1016/j.bbamem.2012.10.023

Cero, C., Vostrikov, V. V., Verardi, R., Severini, C., Gopinath, T., Braun, P. D., et al. (2014). The TLQP-21 peptide activates the G-protein-coupled receptor C3aR1 via a folding-upon-binding mechanism. Structure 22, 1744-1753. doi: 10.1016/j.str.2014.10.001

Chakraborty, S., Akhter, S., Requena, J. R., and Basu, S. (2015). Probing the conformational dynamics of the bioactive peptide TLQP-21 in solution: a molecular dynamics study. Chem. Biol. Drug Des. 86, 938-944. doi: 10.1111/ cbdd. 12541

Chen, Y. C., Pristera, A., Ayub, M., Swanwick, R. S., Karu, K., Hamada, Y., et al. (2013). Identification of a receptor for neuropeptide VGF and its role in neuropathic pain. J. Biol. Chem. 288, 34638-34646. doi: 10.1074/jbc.M113. 510917

Chernyak, B. V. (1997). Cyclosporin A-sensitive release of $\mathrm{Ca} 2+$ from mitochondria in intact thymocytes. FEBS Lett. 418, 131-134. doi: 10.1016/ S0014-5793(97)01361-6

Clapham, D. E. (2007). Calcium signaling. Cell 131, 1047-1058. doi: 10.1016/j.cell. 2007.11.028

Cocco, C., D’Amato, F., Noli, B., Ledda, A., Brancia, C., Bongioanni, P., et al. (2010). Distribution of VGF peptides in the human cortex and their selective changes in Parkinson's and Alzheimer's diseases. J. Anat. 217, 683-693. doi: 10.1111/j.1469-7580.2010.01309.x

Fairbanks, C. A., Peterson, C. D., Speltz, R. H., Riedl, M. S., Kitto, K. F., Dykstra, J. A., et al. (2014). The VGF-derived peptide TLQP-21 contributes to inflammatory and nerve injury-induced hypersensitivity. Pain 155, 1229-1237. doi: 10.1016/j.pain.2014.03.012 
Feng, D. D., Zhao, Y. F., Luo, Z. Q., Keating, D. J., and Chen, C. (2008). Linoleic acid induces $\mathrm{Ca} 2+$-induced inactivation of voltage-dependent $\mathrm{Ca} 2+$ currents in rat pancreatic beta-cells. J. Endocrinol. 196, 377-384. doi: 10.1677/JOE-070426

Ferri, G. L., Gaudio, R. M., Cossu, M., Rinaldi, A. M., Polak, J. M., Berger, P., et al. (1995). The "VGF" protein in rat adenohypophysis: sex differences and changes during the estrous cycle and after gonadectomy. Endocrinology 136, 2244-2251.

Hannedouche, S., Beck, V., Leighton-Davies, J., Beibel, M., Roma, G., Oakeley, E. J., et al. (2013). Identification of the C3a receptor (C3AR1) as the target of the VGF-derived peptide TLQP-21 in rodent cells. J. Biol. Chem. 288, 27434-27443. doi: 10.1074/jbc.M113.497214

Hewavitharana, T., Deng, X., Soboloff, J., and Gill, D. L. (2007). Role of STIM and Orai proteins in the store-operated calcium signaling pathway. Cell Calcium 42, 173-182. doi: 10.1016/j.ceca.2007.03.009

Ishikawa, J., Ohga, K., Yoshino, T., Takezawa, R., Ichikawa, A., Kubota, H., et al. (2003). A pyrazole derivative, YM-58483, potently inhibits store-operated sustained Ca2 + influx and IL-2 production in T lymphocytes. J. Immunol. 170, 4441-4449. doi: 10.4049/jimmunol.170.9.4441

Levi, A., Eldridge, J. D., and Paterson, B. M. (1985). Molecular cloning of a gene sequence regulated by nerve growth factor. Science 229, 393-395. doi: 10.1126/ science. 3839317

Levi, A., Ferri, G. L., Watson, E., Possenti, R., and Salton, S. R. (2004). Processing, distribution, and function of VGF, a neuronal and endocrine peptide precursor. Cell Mol. Neurobiol. 24, 517-533. doi: 10.1023/B:CEMN.0000023627. 79947.22

Li, J. H., Zhao, S. T., Wu, C. Y., Cao, X., Peng, M. R., Li, S. J., et al. (2013). Storeoperated $\mathrm{Ca} 2+$ channels blockers inhibit lipopolysaccharide induced astrocyte activation. Neurochem. Res. 38, 2216-2226. doi: 10.1007/s11064-013-1130-0

Liantonio, A., Giannuzzi, V., Cippone, V., Camerino, G. M., Pierno, S., and Camerino, D. C. (2007). Fluvastatin and atorvastatin affect calcium homeostasis of rat skeletal muscle fibers in vivo and in vitro by impairing the sarcoplasmic reticulum/mitochondria Ca2+-release system. J. Pharmacol. Exp. Ther. 321, 626-634. doi: 10.1124/jpet.106.118331

Liou, J., Kim, M. L., Heo, W. D., Jones, J. T., Myers, J. W., Ferrell, J. E. Jr., et al. (2005). STIM is a Ca2+ sensor essential for Ca2+-store-depletion-triggered Ca2+ influx. Curr. Biol. 15, 1235-1241. doi: 10.1016/j.cub.2005.05.055

Macmillan, D., and McCarron, J. G. (2010). The phospholipase C inhibitor U73122 inhibits $\mathrm{Ca}(2+)$ release from the intracellular sarcoplasmic reticulum $\mathrm{Ca}(2+)$ store by inhibiting $\mathrm{Ca}(2+)$ pumps in smooth muscle. Br. J. Pharmacol. 160, 1295-1301. doi: 10.1111/j.1476-5381.2010.00771.x

Muccioli, G., Ghe, C., Ghigo, M. C., Papotti, M., Arvat, E., Boghen, M. F., et al. (1998). Specific receptors for synthetic GH secretagogues in the human brain and pituitary gland. J. Endocrinol. 157, 99-106. doi: 10.1677/joe.0. 1570099

Muccioli, G., Papotti, M., Locatelli, V., Ghigo, E., and Deghenghi, R. (2001). Binding of 125I-labeled ghrelin to membranes from human hypothalamus and pituitary gland. J. Endocrinol. Invest. 24, RC7-RC9. doi: 10.1007/bf033 43831

Nadeau, S. I., and Landry, J. (2007). Mechanisms of activation and regulation of the heat shock-sensitive signaling pathways. Adv. Exp. Med. Biol. 594, 100-113. doi: 10.1007/978-0-387-39975-1_10

Noli, B., Brancia, C., D’Amato, F., Ferri, G. L., and Cocco, C. (2014). VGF changes during the estrous cycle: a novel endocrine role for TLQP peptides? PLoS ONE 9:e108456. doi: 10.1371/journal.pone.0108456

Petrocchi, P., Quaresima, S., Mongiardi, M. P., Severini, C., and Possenti, R. (2010). Activation of kinase phosphorylation by heat-shift and mild heat-shock. Cell Biol. Int. Rep. 17:e00002. doi: 10.1042/CBR20100002

Possenti, R., Muccioli, G., Petrocchi, P., Cero, C., Cabassi, A., Vulchanova, L., et al. (2012). Characterization of a novel peripheral pro-lipolytic mechanism in mice: role of VGF-derived peptide TLQP-21. Biochem. J. 441, 511-522. doi: 10.1042/BJ20111165

Razzoli, M., Bo, E., Pascucci, T., Pavone, F., D’Amato, F. R., Cero, C., et al. (2012). Implication of the VGF-derived peptide TLQP-21 in mouse acute and chronic stress responses. Behav. Brain Res. 229, 333-339. doi: 10.1016/j.bbr.2012.01.038

Rizzi, R., Bartolomucci, A., Moles, A., D’Amato, F., Sacerdote, P., Levi, A., et al. (2008). The VGF-derived peptide TLQP-21: a new modulatory peptide for inflammatory pain. Neurosci. Lett. 441, 129-133. doi: 10.1016/j.neulet.2008. 06.018

Roos, J., DiGregorio, P. J., Yeromin, A. V., Ohlsen, K., Lioudyno, M., Zhang, S., et al. (2005). STIM1, an essential and conserved component of store-operated Ca2+ channel function. J. Cell Biol. 169, 435-445. doi: 10.1083/jcb.200502019

Ruetschi, U., Zetterberg, H., Podust, V. N., Gottfries, J., Li, S., Hviid Simonsen, A., et al. (2005). Identification of CSF biomarkers for frontotemporal dementia using SELDI-TOF. Exp. Neurol. 196, 273-281. doi: 10.1016/j.expneurol.2005. 08.002

Salton, S. R., Ferri, G. L., Hahm, S., Snyder, S. E., Wilson, A. J., Possenti, R., et al. (2000). VGF: a novel role for this neuronal and neuroendocrine polypeptide in the regulation of energy balance. Front. Neuroendocrinol. 21:199-219. doi: 10.1006/frne.2000.0199

Severini, C., Ciotti, M. T., Biondini, L., Quaresima, S., Rinaldi, A. M., Levi, A., et al. (2008). TLQP-21, a neuroendocrine VGF-derived peptide, prevents cerebellar granule cells death induced by serum and potassium deprivation. J. Neurochem. 104, 534-544. doi: 10.1111/j.1471-4159.2007.05068.x

Shoichet, B. K., and Kobilka, B. K. (2012). Structure-based drug screening for G-protein-coupled receptors. Trends Pharmacol. Sci. 33, 268-272. doi: 10.1016/ j.tips.2012.03.007

Soboloff, J., Rothberg, B. S., Madesh, M., and Gill, D. L. (2012). STIM proteins: dynamic calcium signal transducers. Nat. Rev. Mol. Cell Biol. 13, 549-565. doi: $10.1038 / \mathrm{nrm} 3414$

Stephens, S. B., Schisler, J. C., Hohmeier, H. E., An, J., Sun, A. Y., Pitt, G. S., et al. (2012). A VGF-derived peptide attenuates development of type 2 diabetes via enhancement of islet beta-cell survival and function. Cell Metab. 16, 33-43. doi: 10.1016/j.cmet.2012.05.011

Thastrup, O., Dawson, A. P., Scharff, O., Foder, B., Cullen, P. J., Drobak, B. K., et al. (1989). Thapsigargin, a novel molecular probe for studying intracellular calcium release and storage. Agents Actions 27, 17-23. doi: 10.1007/BF02222186

Trani, E., Giorgi, A., Canu, N., Amadoro, G., Rinaldi, A. M., Halban, P. A., et al. (2002). Isolation and characterization of VGF peptides in rat brain. Role of PC1/3 and PC2 in the maturation of VGF precursor. J. Neurochem. 81, 565-574. doi: 10.1046/j.1471-4159.2002.00842.x

Verkhratsky, A. J., and Petersen, O. H. (1998). Neuronal calcium stores. Cell Calcium 24, 333-343. doi: 10.1016/S0143-4160(98)90057-4

Conflict of Interest Statement: The authors declare that the research was conducted in the absence of any commercial or financial relationships that could be construed as a potential conflict of interest.

The reviewer $\mathrm{JH}$ and handling Editor declared their shared affiliation, and the handling Editor states that the process nevertheless met the standards of a fair and objective review.

Copyright (C) 2017 Molteni, Rizzi, Bresciani, Possenti, Petrocchi Passeri, Ghè, Muccioli, Fehrentz, Verdié, Martinez, Omeljaniuk, Biagini, Binda, Rivolta, Locatelli and Torsello. This is an open-access article distributed under the terms of the Creative Commons Attribution License (CC BY). The use, distribution or reproduction in other forums is permitted, provided the original author(s) or licensor are credited and that the original publication in this journal is cited, in accordance with accepted academic practice. No use, distribution or reproduction is permitted which does not comply with these terms. 